\title{
THE PRIVY COUNCIL AND THE DIFFICULTY OF DISTANCE
}

\section{PAUL MITCHELL ${ }^{*}$}

Keywords: Privy Council, legal history, adjudication

\begin{abstract}
In 1828, in the course of delivering his famous speech on law reform to the House of Lords, Henry Brougham identified "the difficulty... arising of necessity from our distance" as the great challenge faced by the Privy Council. This article explores the strategies subsequently used by the Privy Council in its attempts to overcome that difficulty. Some of these strategies involved the court appearing to move closer to the jurisdiction from which the appeal had come. These included being seen to apply foreign standards in its decisions, positioning its analyses against the grain of traditional English doctrines and making use of the expertise of former colonial judges. Other strategies implicitly asserted that distance was irrelevant by appealing to universal principles, to policy and to general common sense. Occasionally the Privy Council felt that the difficulty of distance loomed so large that it was inappropriate to decide the case. By using these different strategies skilfully and opportunistically, the Privy Council managed to maintain both its legal credibility and its moral authority, in spite of the formidable difficulties of distance with which it continued to be faced.
\end{abstract}

\footnotetext{
* Professor of Laws, UCL (p.mitchell@ucl.ac.uk). I am grateful to Stuart Anderson and Mark Lunney for their comments on this piece.
} 
The difficulty... arising of necessity from our distance, an unavoidable incident to our colonial empire, may almost be deemed an incapacity, for it involves both ignorance of the law, and unfitness to judge of the facts.

Henry Brougham

\section{The Difficulty}

In 1828, in the course of delivering his famous speech on law reform to the House of Commons, Henry Brougham turned his attention to the Privy Council's jurisdiction over what he called "Plantation appeals". The members of the Privy Council, he explained ${ }^{1}-$

are thus made the supreme judges, in the last resort, over every one of our foreign settlements, whether situated in those immense territories which you possess in the East; where you and a trading company together rule over not less than seventy millions of subjects; or are established among those rich and populous lands which stud the Indian Ocean, and form the great Eastern Archipelago; or have their stations in those lands, part lying within the Tropics; part stretching towards the Pole, peopled by various castes differing widely in habits, still more widely in privileges; great in numbers, abounding in wealth, extremely unsettled in their notions of right, and excessively litigious, as all the children of the New World are supposed to be, both from their physical and political constitution. All

\footnotetext{
${ }^{1} \mathrm{HC}$ Deb, $2^{\text {nd }}$ series, 7 February 1828 , vol 18 , cols $154-5$.
} 
this immense jurisdiction over the rights of property and person, over rights political and legal; and all the questions growing out of such a vast and varied province, is exercised by the Privy Council unaided and alone. It is obvious that, from mere distance of those colonies, and the immense variety of matters arising in them, foreign to our habits, and beyond the scope of our knowledge, any judicial tribunal in this country must, of necessity, be an extremely inadequate court of review.

This was challenging enough; but Brougham went on to explain that there were further problems:

what adds incredibly to the difficulty is, that hardly any two of the colonies can be named which have the same law; and in the greater number the law is wholly unlike our own. In some Settlements, it is the Dutch law; in others the Spanish, in others the French, in others the Danish. In our Eastern possessions these variations are, if possible, yet greater: while one territory is swayed by the Mohammedan law, another is ruled by the native or Hindu law, and this again, in some of our possessions, is qualified or superseded by the law of Budda, the English jurisprudence being confined to the handful of British settlers, and the inhabitants of the three presidencies. All these laws must come, in their turns, in review, before the necessarily ignorant privy councillor, after the learned doctors in each have differed. 
"The difficulty thus arising of necessity from our distance", he concluded, "an unavoidable accident to our colonial empire, may almost be deemed an incapacity, for it involves both ignorance of the law, and unfitness to judge of the facts."2

Brougham's identification of the difficulty of distance as the Privy Council's major - and, one could almost say, its defining - weakness was a characteristically perceptive insight. As the passage read as a whole makes clear, he was not making a mundane point about the length and expense of journeys that litigants and their representatives might have to undertake in order to attend a hearing of the Privy Council; nor was he seeking to emphasise the delays in litigation that such journeys would inevitably cause. "Distance" was being used as much figuratively as literally: it was not so much the physical distance in itself that mattered, as the remoteness, unfamiliarity and sheer foreignness that the physical distance entailed. There were unique governmental arrangements to contend with, dramatic contrasts in the distribution of wealth, and enormous variations in climate, all of which were significant in themselves and shaped the habits and expectations of the inhabitants. A court merely seeking to apply English law principles to such very diverse societies would already have faced some nice problems calling for sophisticated and sensitive solutions. As it was, the task was even more delicate: Privy Council members were required to adjudicate on questions of whatever law happened to be in force in the jurisdiction from which the appeal had been brought. As the British Empire grew, so did the number of legal systems from which questions might come to the Privy Council. Brougham's catalogue of systems illustrated the eclectic demands of the Privy Council's remit in the early nineteenth century; and life was no simpler for early twentieth century members of the Judicial Committee. As Frederick Pollock recorded in 1906, the Privy Council could be required to pronounce on systems as diverse as Quebec's “essentially French law and procedure”, the Isle of Man's "peculiar body of laws of

\footnotetext{
${ }^{2}$ Ibid col 155.
} 
ancient, apparently Scandinavian origin" and "the possible variations of Hindu law by special custom" applicable in India. ${ }^{3}$ Mauritius and the Straits Settlements presented different problems, as they blended English law with other elements. ${ }^{4}$

Brougham regarded the difficulty of distance as so severe that it might "almost be deemed incapacity". At first glance the claim looks exaggerated - the Privy Council's "capacity", we might be tempted to reply, was determined by British constitutional arrangements in which any difficulty of distance was irrelevant. Brougham, however, was surely using the idea of incapacity in a more evaluative and illuminating way, to denote the Privy Council's ability to carry out its role as the Empire's court of final appeal. Taken in this sense, the implications of the difficulty of distance were indeed formidable, because they prevented the Privy Council from being able to rely on two traditionally compelling bases for recognising a court's (moral) authority. The first was technical expertise: as Brougham recognised, it was simply not possible to claim superior knowledge on the part of Privy Council members when appeals could be brought from such an eclectic array of jurisdictions. The second basis was social solidarity, an idea which was particularly powerful in a common law system, where - at least in theory - the law was thought to be grounded in social acceptance. Again, it was not obviously plausible for the Privy Council to be claiming to be in touch with the relevant society's needs and aspirations - the court was, by definition, remote from the society to which its pronouncements would apply. In short, the difficulty of distance had the potential to undermine both the court's moral authority and the credibility of its judgments.

\footnotetext{
${ }^{3}$ F Pollock, 'The Jurisdiction of the Privy Council' (1906) 7 Journal of the Society of Comparative Legislation 330. The quotations are from pages 330 and 331. For an overview of the business of the Privy Council to 1914 see W Cornish, J S Anderson, R Cocks, M Lobban, P Polden and K Smith, The Oxford History of the Laws of England: Volume XI: 1820-1914 English Legal System (Oxford, 2010) 550-557.

${ }^{4}$ Pollock (n 3) 331, 332.
} 
That potential, however, would not be realised, and the Judicial Committee of the Privy Council - created on Brougham's initiative in 1833 - continues to function as the final court of appeal for several jurisdictions even today. Its longevity is surprising given the inevitable vulnerabilities to which the difficulty of distance gives rise. The purpose of this article is to look closely at a selection of the court's jurisprudence where issues of distance loomed large, to analyse revealing extra-curial writings about the court and its judges, and to consider the significance of Parliamentary discussions of the Privy Council's role. The article argues that the Privy Council skilfully managed the difficulty by deploying a range of techniques that, not entirely self-consistently, sometimes disguised, sometimes acknowledged, and, most commonly, marginalised distance.

\section{Location in Practice and Theory}

Perhaps the most striking way in which the Privy Council sought to disguise the difficulty of distance was by pretending that the court was somewhere else. There were, indeed, occasional suggestions that it should, quite literally, be somewhere else - with, for instance, Indian appeals being heard in India ${ }^{5}$ - but these suggestions came to nothing, and it remained in its Downing Street home. However, that did not preclude a little armchair travel. As the Registrar to the Privy Council, Sir Charles Neish, explained in $1929,{ }^{6}$

\footnotetext{
${ }^{5}$ G Rankin, 'The Judicial Committee of the Privy Council' (1939-1941) 7 Cambridge Law Journal 2, 11; R De,

“"A Peripatetic World Court” Cosmopolitan Courts, Nationalist Judges and the Indian Appeal to the Privy Council' (2014) 32 Law and History Review 821. Cf R Haldane, 'The Appellate Courts of the Empire' (1900) 12 Juridical Review 1, 7-8, who would have transferred the Privy Council permanently to the House of Lords.

${ }^{6}$ Quoted in P Howell, The Judicial Committee of the Privy Council 1833-1876 (Cambridge University Press, 1979) 215 .
} 
In the Privy Council the theory has always prevailed that when the Board is hearing an Appeal from any dependency of the Crown, it is in effect sitting as a Court of that dependency, and local counsel can appear subject to exactly the same conditions as those under which they could appear in the Court appealed from.

Such equivocation - to be in London in reality and elsewhere in "theory" - was also, apparently, achieved by the best judges. Sir James Colvile was praised for his "instinct to survey a question with the eyes at once of an Englishman and a Hindoo". ${ }^{7}$ Lord Haldane went further, writing admiringly of Lord Watson's ability to inhabit whichever legal system was involved in a Privy Council appeal. For Haldane, Watson was "the Privy Council Judge par excellence ... he never failed to endeavour to interpret the law according to the spirit of the jurisprudence of the Colony from which the appeal came. If it was a Cape appeal, he was a Roman Dutch lawyer; if it was an Indian case of adoption, he entered into the religious reasons for the rule to be applied". ${ }^{8}$ The process is made to sound like impersonation, or, at the very least, assuming a theatrical role. Later commentators have been less generous to Watson, feeling that he was too quick to abandon his Scottish heritage when questions were raised about the distinctive character of Scots law. ${ }^{9}$ For our purposes, however, what is

\footnotetext{
${ }^{7}$ The Times (London, 9 December 1880) 9 (untitled article prompted by the death of Sir James Colvile reported the previous day). See further, K Prior, 'Colvile, Sir James William (1810-1880), judge in India' in Oxford Dictionary of National Biography (online edition).

${ }^{8}$ R Haldane, 'The Appellate Courts' (n 5) 5.

${ }^{9}$ See the comments in J Rigg, rev W Gordon, 'Watson, William, Baron Watson (1827-1899), judge' in Oxford Dictionary of National Biography (online ed) on Watson's speech in Mayor, Aldermen and Burgesses of the Borough of Bradford $v$ Pickles [1895] AC 587; compare the comments on the same case in the obituary in The Times (London, 15 September 1899) 6.
} 
important is not so much Watson's actual achievements as Haldane's perception of what the ideal Privy Council judge should do.

Other judges may have lacked Watson's chameleon-like ability to adapt to his legal surroundings, but they often went out of their way to signal that they were not rigidly applying English standards to the cases they heard. One dramatic illustration is provided by McLeod v St Aubyn ${ }^{10}$, in which Watson was a member of the Board, but did not deliver its advice. The facts revealed a grotesque abuse of power on the part of the respondent, who, as the acting Chief Justice of St Vincent, had sentenced the appellant to fourteen days imprisonment for contempt of court for lending a newspaper that the appellant had not yet read to a public library (whose own copy had been delayed in the post). The newspaper contained material attacking the respondent's professional integrity. In the course of allowing the appeal, the Board emphasised many of the points that we might have expected, such as the objectionable use of contempt proceedings to protect the judge's personal reputation, and the "extraordinary" scope of the offence if it really could be committed inadvertently. ${ }^{11}$ However, the Board made it very clear that the case was not to be judged by English metropolitan standards: "it must be considered", they stated, "that in small colonies, consisting principally of coloured populations, the enforcement in proper cases of committal for contempt of Court for attacks on the Court may be absolutely necessary to preserve in such a community the dignity of and respect for the Court". ${ }^{2}$ The Board was, it seems, anxious to be seen to appreciate the different standards called for by Caribbean conditions, and showed its appreciation in a striking way. Evidently it was seeking to overcome the difficulty of distance by using empathy, but it was not attempting to empathise with the local

\footnotetext{
${ }^{10}[1899]$ AC 549.

${ }^{11}[1899]$ AC 549, 561-562.

${ }^{12}[1899]$ AC 549, 561.
} 
population; it was, instead, imagining itself in the position of the colonial judges from whose decisions it was hearing appeals.

A different kind of refusal to apply British standards could be seen in the very different context of general damages for personal injury. The accurate quantification of such damages has been a perennial problem in English law since the middle of the last century, when jury assessment was phased out, and it has remained impossible to identify a method for calculating exact sums. Instead, the emphasis has come to be on consistency between awards, and on maintaining a coherent scale reflecting relative seriousness of harm. ${ }^{13}$ Overseas courts applying English law faced identical difficulties, but with an added twist when it came to identifying appropriate comparators to inform their assessment: should awards in other jurisdictions be taken into account, and, if so, which jurisdictions? English courts, it seems, have never needed to address this question.

What remains the fundamental guideline was articulated by Lord Morris of Borth-y-Gest in Jag Singh v Toong Fong Omnibus Co $\mathrm{Ltd}^{14}$, a case in which the Court of Appeal of Malaya had referred to Singaporean awards of general damages. "To the extent to which regard should be had to the range of awards in other cases which are comparable", it was said, "such cases should as a rule be those which have been determined in the same jurisdiction or a neighbouring locality where similar social, economic and industrial conditions exist". ${ }^{15}$ Later, the instinctive feeling that general damages for personal injury were expressive of socioeconomic conditions led the Privy Council to decline to exercise a power, conferred on it by the Constitution of Trinidad and Tobago, to substitute its own award where the local court's

\footnotetext{
${ }^{13}$ A Ogus, "Damages for Lost Amenities: For a Foot, a Feeling or a Function?" (1972) 35 MLR 1; Heil v Rankin [2001] QB 272.

${ }^{14}$ [1964] 1 WLR 1382.

${ }^{15}$ [1964] 1 WLR 1382, 1385.
} 
was erroneous: only a Judge of the Trinidadian High Court, they sensed, would have the requisite local knowledge. ${ }^{16}$

Perhaps the most suggestive of the cases on general damages for personal injury was Chan Wai Tong v Li Ping Sum ${ }^{17}$, where a defendant objected to a Hong Kong Court's reference to English awards. The Privy Council held that the reference had had no effect on the Hong Kong court's assessment, but took the opportunity to reiterate the position set out in the Jag Singh case: "a court should in general have regard only to awards in the same jurisdiction or in a neighbouring locality where the relevant conditions are similar". ${ }^{18}$ England, on this principle, was not a comparable jurisdiction: "unless and until the courts in Hong Kong are satisfied that social and economic conditions, including especially the rate of earnings, in Hong Kong are similar to those in England", English awards were to be disregarded. ${ }^{19}$ The Privy Council's reasoning helpfully articulated the relationship between between general damages for personal injury and other, ostensibly distinct, wider phenomena; but perhaps the most interesting factor in the case was the argument to which the Privy Council was responding. For the Court of Appeal of Hong Kong had hinted at a very different method of comparison when it observed that awards in England were approximately three times higher than those in Hong Kong, and "it is difficult to understand why there should be such startling disparity between the levels of awards in the two jurisdictions". ${ }^{20}$ The implication was that,

\footnotetext{
${ }^{16}$ Selvanayagam v University of the West Indies [1983] 1 WLR 585; cf Ratnasingam v Kow Ah Dek [1983] 1 WLR 1235, where the overriding importance of finality in litigation prompted the Privy Council to make its own assessment of special damages in a personal injury case.

${ }^{17}[1985] 1$ AC 446.

${ }^{18}$ [1985] 1 AC 446, 456.

${ }^{19}$ [1985] 1 AC 446, 457.

${ }^{20}$ [1985] 1 AC 446, 455.
} 
irrespective of socio-economic context, Hong Kong Courts were undervaluing the pain, suffering and loss of amenity of claimants, and needed to readjust their awards. The Privy Council's rejection of this position tells us something rather disheartening about deferring to the difficulty of distance. Undoubtedly the legal rules retain a certain authenticity, and consistency with their socio-economic context, but what we might call the benefits of distance - the opportunity to put things in a wider perspective, and to draw illuminating comparisons - are lost. There is also a rather defeatist attitude to the relationship between law and social change inherent in the Privy Council's reasoning, for it assumes that while socioeconomic changes may necessitate legal change, the relationship is only one-way. The potential for legal changes (such as an increase in personal injury damages awards) to contribute to social changes (such as more responsible attitudes to workplace and road safety) is disallowed. Finally, we might pause to register the oddity, the almost Alice in Wonderland quality, of a London-based panel of English and Scottish judges insisting on Hong Kong localism, in the face of attempts by Hong Kong judges to Anglicise their personal injury awards. Where the Privy Council was - whether in fact or in theory - gave little indication of its agenda.

\section{Respect for Colonial Governance}

One area in which the Privy Council could almost be relied upon to define itself against its location was in matters of colonial governance. The Privy Council's Downing Street base might, perhaps, have been expected to predispose it towards arguments restricting colonial autonomy, or invoking English constitutional truisms; but the court consistently rejected such arguments. Two striking illustrations are provided by Attorney-General for New South Wales 
$v$ Rennie $^{21}$ and Gould $v$ Stuart ${ }^{22}$, both appeals from New South Wales, which were decided within three months of each other. Rennie's case involved what, at first glance, looked to be a rather abstruse question of statutory construction: did "Legislative Assembly" in the Parliamentary Representatives' Allowance Act (53 Vict no 12) refer only to the Legislative Assembly existing at the date of the Act? If so, the consequences were dramatic (and explain why the case reached the Privy Council): another piece of New South Wales legislation had limited the term of Legislative Assemblies to five years; the Legislative Assembly existing at the time the Parliamentary Representatives' Allowance Act was passed had been dissolved; so it followed - if the appellant's interpretation was correct - that no allowances could be claimed by members of the current Legislative Assembly. The Privy Council's decision that the allowances remained claimable showed that it appreciated the wider ramifications of the decision. “"Legislative Assembly', said Sir Richard Couch,

means the Assembly created by the Constitution Act, which, though liable to be dissolved or to expire by effluxion of time, is an essential part of the constitution of the colony and must be regarded as a permanent body. If it was considered to be just or proper to give an allowance for expenses to the members of the existing Assembly, it may be reasonably presumed to be equally so to give the same allowance to the members of a future Assembly. ${ }^{23}$

The Legislative Assembly, and, by implication, other constitutional organs in New South Wales, were not to be seen as tentative experiments, subject to cancellation if results proved unsatisfactory. On the contrary, they were legitimate, established institutions for which appropriate ancillary arrangements were needed. There is not the slightest trace in the Privy

\footnotetext{
${ }^{21}$ [1896] AC 376.

${ }^{22}$ [1896] AC 575.

${ }^{23}$ [1896] AC 376, 379-380.
} 
Council's decision of any sympathy with the idea that self-government was conditional, or revocable.

Gould $v$ Stuart $^{24}$ raised questions of self-determination in the rather different context of the Crown's right to dismiss its officers at will. The respondent had been employed as a government clerk, and claimed that he had been wrongfully dismissed, but the appellant argued that the Crown in New South Wales retained the power to dismiss civil servants at its pleasure. The respondent admitted that dismissal at pleasure was the traditional common law position, but relied on the Civil Service Act 1884 (NSW) as having transformed the position in New South Wales. Under that Act procedures were created for the suspension, demotion and dismissal of civil servants, and the Privy Council agreed with the respondent that those procedures were decisive:

These provisions, which are manifestly intended for the protection and benefit of the officer, are inconsistent with importing into the contract of service the term that the Crown may put an end to it at its pleasure. In that case they would be superfluous, useless, and delusive. This is, in their Lordships' opinion, an exceptional case, in which it has been deemed for the public good that a civil service should be established under certain regulations with some qualification of the members of it, and that some restriction should be imposed on the power of the Crown to dismiss them. ${ }^{25}$

The Crown was not to be allowed to fall back on its arbitrary common law powers when it had previously found it expedient to sign those powers away.

\footnotetext{
${ }^{24}$ [1896] AC 575.

${ }^{25}$ [1896] AC 575, 578-579.
} 
A similar theme could be seen in a cluster of cases in the 1880 s on the Crown's immunity from suit in contract and tort. In the first, Palmer $v$ Hutchinson $^{26}$, the Privy Council insisted on what was then the orthodox line that the Crown could not be liable for breach of contract, and neither could the Crown officer who had concluded the contract, unless he had contracted personally. ${ }^{27}$ In reaching the opposite conclusion, the Supreme Court of Natal had relied on the local practice of a public officer being sued on contracts made in his official capacity, and on an earlier Privy Council decision where it was assumed that such an action would lie. ${ }^{28}$ Both factors were peremptorily dismissed by the Privy Council, in a decision that made it sound as if the position was simple.

Shortly afterwards, however, in Hettihewage Siman Appu v Queen's Advocate ${ }^{29}$, the Privy Council distinguished Palmer v Hutchinson when holding that the Crown could be sued for breach of contract in Ceylon. As in Palmer's case, the claimant relied on a local practice of allowing the Crown to be sued, but the argument was better received than it had been in the earlier case. Here, the Privy Council emphasised, the case was different, because a local Ordinance of 1868 had recognised - albeit in general language - that such actions could be brought. Counsel for the Crown had suggested that some clearer statutory language was needed, and had emphasised that allowing claims against the Crown would be a radical departure from Ceylon's Roman-Dutch roots, since it was "impossible" to suppose, in that system, that the monarch would "submit to the indignity of being sued". ${ }^{30}$ The Privy

\footnotetext{
${ }^{26}$ (1881) 6 App Cas 619.

${ }^{27}$ Macbeath v Haldimand (1786) 1 TR 172; Prosser v Allen (1819) Gow 117; Gidley v Lord Palmerston (1822)

3 Brod \& B 275.

${ }^{28}$ Van Rooyen v Reit (1838) 2 Moo 177.

${ }^{29}$ (1884) 9 App Cas 571.

${ }^{30}$ (1884) 9 App Cas 571, 584.
} 
Council's response was striking. Sixteenth century Scots procedural law, they pointed out, permitted the king to be sued via his officers - claims were thus not only possible, but had actually occurred - and, whilst it was true that no reported instances of claims against the monarch in Roman-Dutch law could be found, the absence of such claims was readily explicable by political circumstances rather than legal principles. ${ }^{31}$ In Ceylon, where claimants were less inhibited, the denial of a right to sue for breach of contract would be "inconvenient", because the petition of right procedure - which was the means by which English claimants were able to bring contractual claims against the Crown - had never been extended to Ceylon. ${ }^{32}$ These historical and contextual factors cast new light on the Ceylonese courts' practice of allowing claims: "Whatever may be the exact origin of the practice of suing the Crown, it was doubtless established to avoid such glaring injustice as would result from the entire inability of the subject to establish his claims". ${ }^{33}$

The most striking features of the Privy Council's analysis here were its emphases on empiricism, relativism and local context. The apparently eternal truth that no monarch would submit to the indignity of actions in ordinary courts was first undermined by historical evidence, then repositioned as a statement of contingent political reality rather than legal principle, and finally declared inapplicable to Ceylon. It was an analysis that worked by methodically distancing itself from a proposition that was axiomatic for English lawyers (and would continue to be so until the Crown Proceedings Act 1947), and by substituting a rule that was responding to local conditions.

The relativity of self-evident constitutional truths came to the fore in the final two cases of the cluster. Both concerned the proposition - it was almost a slogan - that "the King could do

\footnotetext{
${ }^{31}$ (1884) 9 App Cas 571, 584-585.

32 (1884) 9 App Cas 571, 587.

33 (1884) 9 App Cas 571, 587.
} 
no wrong". ${ }^{34}$ The first, Farnell v Bowman ${ }^{35}$ was an appeal from New South Wales, where the Supreme Court had been divided over whether the Claims Against the Government Act 1876 (NSW) permitted tort claims to be brought against the government. ${ }^{36}$ Martin CJ took the view that the statutory wording was insufficiently clear. "It is one of the undoubted prerogatives of the Crown", he said, "not to be sued for damages in an action ex delicto, and neither that nor any other of the prerogatives can be taken away by implication". ${ }^{37} \mathrm{He}$ also took the opportunity to deliver some bracing remarks about New South Wales' status - "The government of this British colony", he explained, "however much ignorant people may be unable to comprehend it, is still the Government of the Queen". ${ }^{38}$ Martin CJ's colleague Faucett J seems to have been one of those "ignorant people": for him, the reference in the Act to "Her Majesty's local Government" meant the Governor and Executive Council. He also disagreed with Martin CJ on the issue of statutory construction, taking the view that the broad language of the section, which included the phrase "any just claim or demand whatever", had to embrace claims in tort. This interpretation was confirmed by a consideration of the local context:

when we consider the great variety of transactions which the Colonial Government undertakes and carries on, the old maxim seems in a large degree inapplicable to the state of things existing here, and we must presume that the Legislature, having this state of things in view, altered the law to meet the altered circumstances.

\footnotetext{
${ }^{34}$ The classic exposition of the rule is Raleigh $v$ Goschen [1898] $1 \mathrm{Ch} 73$.

35 (1887) 12 App Cas 643.

${ }^{36}$ Bowman v Farnell (Minister of Lands) (1886) 7 NSWR 1.

${ }^{37}$ (1886) 7 NSWR 1, 5.

${ }^{38}$ (1886) 7 NSWR 1, 6.
} 
Windeyer J tentatively agreed with Faucett J.

The Privy Council upheld the majority's decision and echoed the emphasis on the statutory language. It also agreed with, and elaborated on, the point about the range of governmental activities: $:^{39}$

It must be borne in mind that the local Governments in the Colonies, as pioneers of improvements, are frequently obliged to embark in undertakings which in other countries are left to private enterprise, such, for instance, as the construction of railways, canals, and other works for the construction of which it is necessary to employ many inferior officers and workmen. If, therefore, the maxim that "the king can do no wrong" were applied to Colonial Governments in the way now contended for by the appellants, it would work greater hardship than it does in England.

The essential point in this passage was the same as the point made by Faucett $\mathrm{J}$ in the court below, but, when the two expositions are placed side by side, two telling differences can be seen. First, there is a difference in assumed audience. Faucett $J$ speaks of "the state of things existing here", and is implicitly addressing fellow Australians. The Privy Council seems to have a different audience in view - the analysis is couched in terms of justifying a departure from traditional English precepts, and "It must be borne in mind..." sounds like an attempt to forestall implicitly English objections. The assumed audience here is a sceptical English one. The second difference is the breadth of the reasoning. Where Faucett $\mathrm{J}$ speaks of "the

\footnotetext{
39 (1887) 12 App Cas 643, 649. The advice was delivered by Sir Barnes Peacock. For Peacock’s earlier (Indian) innovation in this area see S Anderson, 'Central Executive: The Legal Structure of State Institutions' in W Cornish et al, The Oxford History of the Laws of England: Volume XI: 1820-1914 English Legal System (OUP, 2010) 380-381; for the wider context see S Anderson, '"Grave injustice', 'despotic privilege': the insecure foundations of crown liability for torts in New Zealand' (2009) 12/1 Otago Law Review 1, 5-10.
} 
Colonial Government", the Privy Council talks of "the local Governments in the Colonies"; Faucett J's specific contrast between New South Wales and England becomes a general analytical tool for use anywhere in the Empire. Less than a year later, in Attorney-General of the Straits Settlement $v$ Wemyss ${ }^{40}$, the Privy Council had no hesitation in applying it to a claim arising from government reclamation works in Penang. "In the case of Farnell $v$ Bowman", the Board recalled,

attention was directed by this Committee to the fact that in many colonies the Crown was in the habit of undertaking works which, in England, are usually performed by private persons, and to the consequent expediency of providing remedies for injuries committed in the course of these works. The present case is an illustration of that remark. And there is no improbability, but the reverse, that when the legislature of a Colony in such circumstances allows claims against the Crown in words applicable to claims upon torts, it should mean exactly what it expresses. $^{41}$

It followed that a tort claim against the government was authorised by a local Ordinance that permitted claims against the Crown "for damages or compensation arising in the Colony". Again, a comparison of the Board's language with the terms used by Faucett $\mathrm{J}$ to make the same basic point is revealing: for Faucett $\mathrm{J}$ New South Wales was the exception to the "old maxim"; for the Privy Council in Attorney-General of the Straits Settlement $v$ Wemyss, by contrast, England was the odd one out. The essential point may have been the same, but its emphasis had been reversed, its tone had been transformed, and its logic now pointed towards a reform of the English doctrine.

\footnotetext{
40 (1888) 13 App Cas 192.

${ }^{41}$ (1888) 13 App Cas 192, 197.
} 
Many of the most interesting features of the cases considered in this section can be seen as responses to the difficulty of distance. Privy Council members seem to have been particularly anxious about appearing to be out of touch, and went out of their way to emphasise their grasp of local conditions. The results could occasionally look odd - as in Farnell v Bowman, where the Privy Council was far more respectful of New South Wales' autonomy than its own Chief Justice had been - but the determination to support colonial self-determination was both consistent and admirable. There was also quite a radical undertone to some of the jurisprudence. For, even though the cases were technically limited to the interpretation of foreign legislation, the Privy Council's underlying scepticism about Crown immunity from claims in contract and tort was obvious. In some ways the most challenging aspect of these decisions was not so much their rationes as their invocation of increasing government activity to support the conclusion that Crown immunities had been abandoned: the implication was, that, far from being universal or self-evident truths, Crown immunities were contingent on political environments. That was a message with quite startling implications beyond the colonial context.

\section{Colonial Experience}

The cases discussed in the previous section did not only share common ideas; they were heard by very similarly constituted panels. Sir Richard Couch delivered the Board's reasons in Attorney-General for New South Wales v Rennie and Gould v Stuart, as well as sitting in Palmer v Hutchinson, Hettihewage Siman Appu v Queen's Advocate and Bowman v Farnell. Lord Hobhouse sat in every case, and gave the Board's reasons in both Hettihewage Siman Appu v Queen's Advocate and Attorney-General of the Straits Settlement v Wemyss. Sir Barnes Peacock wrote for the Board in Palmer v Hutchinson and Bowman v Farnell; he also 
sat in Attorney-General of the Straits Settlement $v$ Wemyss. These judges were hardly household names - even in legal households - indeed, Couch's obituarist would begin his tribute with the statement that "Sir Richard Couch was one of a class of public servants whose work is of truly Imperial importance, but completely fails to attain anything like popular recognition". ${ }^{42}$ That was not to say, however, that they were unqualified, or amateurs. At least part of the explanation for their obscurity in England was the fact that they had had distinguished careers in India.

Peacock had become Legal Member of the Supreme Council of the Viceroy at Calcutta in 1852, and held that post for seven years before being appointed Chief Justice of the Supreme Court of Calcutta. He remained Chief Justice for eleven years and was succeeded by Sir Richard Couch. ${ }^{43}$ At the time of his appointment, Couch already had eight years' Indian judicial experience as, first, a judge, then Chief Justice, of the High Court of Bombay. ${ }^{44}$ While serving as Chief Justice in Calcutta he had met and became friends with Hobhouse, who became Legal Member of the Viceroy's Council in 1872, and retained that post for five years. ${ }^{45}$ The advantages of all three men's Indian experience were most obvious in Indian appeals on questions of family law or inheritance law (where Hindu or Muslim religious laws still applied); Peacock, for instance, was particularly noted for his knowledge of Indian

\footnotetext{
42 'Death of Sir Richard Couch' The Times (London, 30 November 1905) 4. See also C Bedwell, rev D Hardiman, 'Couch, Sir Richard (1817-1905), judge' in Oxford Dictionary of National Biography (online ed).

${ }^{43}$ J Hamilton, rev R Steam, 'Peacock, Sir Barnes (1810-1890), judge' in Oxford Dictionary of National Biography; 'Death of Sir Barnes Peacock' The Times (London, 4 December 1890) 8.

${ }^{44}$ See materials cited in $\mathrm{n} 42$ above.

${ }^{45}$ C Bedwell, rev H Matthew, 'Hobhouse, Arthur, Baron Hobhouse (1819-1904), judge' in Oxford Dictionary of National Biography (online ed); 'Death of Lord Hobhouse' The Times (London, 7 December 1904) 8. The friendship with Couch is recorded in L Hobhouse and J Hammond, Lord Hobhouse A Memoir (Edward Arnold,
} 1905) 66. 
customs. But the more difficult - and intriguing - question concerns the extent to which their Indian experiences might have informed their attitudes to appeals from non-Indian jurisdictions. For, as we have seen, and as contemporary commentators noted appreciatively, both Couch and Hobhouse (and, to a lesser extent, Peacock), threw themselves wholeheartedly into the Privy Council's work, and clearly did not regard themselves as exclusively Indian specialists. ${ }^{46}$ Peacock's is perhaps the most striking case, since he began his Indian duties in the very year that the British position in India was rocked by the Mutiny. ${ }^{47}$ The Mutiny's immediate cause was the supply of cartridges greased with a mixture of cow's fat and pork lard to Indian soliders, and some commentators sought to portray the uprising and its aftermath as an isolated, and regrettable misunderstanding on a specific issue. But more critical analysts identified as underlying causes the ignorance and arrogance of the British authorities, especially those of the East India Company with its transparently commercial motivations. As one of those analysts, Herbert Cowell, later put it, "the Mutiny is the important date at which the whole character of our relations with India underwent a great organic change." 48

Cowell was in an excellent position to know. For, although when he wrote these words in 1897 he was the Privy Council's law reporter (and occasionally an advocate before it), rather like Peacock, Couch and Hobhouse, he had a distinguished Indian career behind him, the centrepiece of which was his tenure of the inaugural Tagore Professorship at the University

\footnotetext{
${ }^{46}$ Eg 'Death of Lord Hobhouse' The Times (London, 7 Dec 1904) 8; 'Death of Sir Richard Couch' The Times (London, 30 November 1905) 4.

${ }^{47}$ D Judd, Empire, The British Imperial Experience from 1765 to the Present (Tauris, 2012) ch 7 provides a short, helpful account.

${ }^{48}$ H Cowell, 'Forty-One Years in India' (1897) 161 Blackwood's Edinburgh Magazine 297, 297.
} 
of Calcutta from 1869 to $1872 .{ }^{49}$ Cowell's duties as Professor were defined in the will of the donor as being to "read or deliver yearly, at some place within the town of Calcutta, one complete course of law lectures, without charge to the students and other persons who may attend such lectures." ${ }^{, 50}$ His first course, on the court system of India, went through six editions, and was described as "something of an Indian legal classic". 51 The second and third courses, on Hindu family, adoption, property and succession law were equally well received: the second course was hailed as "a model of what a treatise on Hindu law should be" the third as "quite equal in value" to its predecessor. ${ }^{53}$ Cowell's assessment of the period immediately following the Mutiny was that it was "one of great legislative activity, of numerous codes of law, designed to weld together as far as possible the heterogeneous populations of the empire". ${ }^{54}$ The latter point was particularly important - these legislative activities were not to be seen as attempts to impose an alien system on an insubordinate population. Indeed, for Cowell, crass attempts to impose British ways had been almost catastrophic: as he described the scene on the eve of the Mutiny, "We were inflated by our power... and were proportionately more dogmatic than compromising in introducing Western

\footnotetext{
${ }^{49}$ Cowell's appointment to the Chair was announced in the legal press: 13 Solicitors' Journal and Reporter 906 (4 September 1869); a summary of his career to 1888 can be found at 32 Solicitors' Journal and Reporter 753 (22 September 1888), accompanying the announcement of his appointment as a magistrate for Suffolk. Cowell's appearances before the Privy Council included Trimati Janoki Devi v Sir Gopal Acharma Goswami, Morning Post (London, 11 December 1882) 6; Mohamadu Mohideen Hadjiar v Pitchey, The Times (London, 11 June 1894) 3; Said Ali v Ibad Ali, The Times (London, 20 June 1895) 3.

5015 Solicitors' Journal and Reporter 578 (10 June 1871), reviewing Cowell's Lectures on Hindu Law.

${ }^{51}$ S FitzGerald, review of History and Constitution of the Courts and Legislative Authorities in India by Herbert Cowell, $6^{\text {th }}$ edition by S Bagchi (1937) 53 LQR 135.

5215 Solicitors' Journal and Reporter 578 (10 June 1871).

53 (1872) 1 Law Magazine and Review 77.

54 'Forty-One Years' (n 48) 298.
} 
reforms and curing Oriental practices by our views of what is sound, regardless of native ideas and tradition." 55

What Cowell described as a period of "great legislative activity... designed to weld together as far as possible the heterogeneous populations of the empire" began with Peacock's tenure as the Law Member of the Viceroy's Council. His subsequent judicial career, like Couch's, was played out in an environment in which judges could not but have been aware of the sensitivity their roles required, and the delicacy of their task. Hobhouse's position was obviously different, in that he held no Indian judicial post; and by the time of his appointment to the Viceroy's Council the enthusiasm for legislation had subsided. He was however, a thoughtful and perceptive observer of the Indian situation, and acutely aware of the difficulties of creating appropriate legislation. ${ }^{56}$ If Kipling's short story, "Tods' Amendment" is anything to go by, Law Members' anxiety about their proposals irritating the local population continued well after Hobhouse's time. ${ }^{57}$ In that story, first published ten years after Hobhouse had left India, an ambitious legislative initiative is recast after a child tells the Law Member what he has heard local people saying about the measure. The story may, perhaps, try too hard to be charming ${ }^{58}$; but both the central premiss of its plot - that the Legislative Council's self-confidence on such issues was cripplingly fragile - and the wider

\footnotetext{
55 'Forty-One Years' (n 48) 304. Cowell's feelings about the activities of the East India Company could be seen in his detailed review of J S Mill's Autobiography, where he made it clear that he regarded Mill's unquestioning service and loyalty to the company as unforgivable: 'John Stuart Mill: An Autobiography' (1874) 115 Blackwood's Edinburgh Magazine 75, 83. For Cowell's views of the imperialism more broadly see 'The Growth of the British Empire' (1896) 159 Blackwood's Edinburgh Magazine 364.

${ }^{56}$ L Hobhouse and J Hammond, Lord Hobhouse (n 45) ch 3, especially at 61-63 (describing Hobhouse's attitude to his role).

${ }^{57}$ R Kipling, Plain Tales From the Hills (first published 1888, Penguin Books, 1990) 179.

${ }^{58}$ D Trotter, 'Introduction' in R Kipling, Plain Tales (n 57) 23.
} 
absurdity of undertaking law reform with no real method of knowing what the local population either wanted or needed, have the ring of truth about them.

The late nineteenth century Privy Council decisions on colonial governance, in which Peacock, Couch and Hobhouse took such leading roles, surely carry the hallmark of these judges' Indian experiences. There is an instinctive refusal to have recourse to English doctrines as default solutions, and a corresponding concern both to take account of colonial conditions, and to signal that those conditions had determined the outcome of the case. There is also an awareness of the importance of supporting (and, thereby, both stabilising and strengthening) local representative government. Perhaps most strikingly, there is a determination not to allow governments to act in a high-handed, unaccountable way - for instance, by the judges' insistence that the Crown can commit a tort, and be liable for it, in the colonies. India offered them an all too vivid reminder of where unchecked executive arrogance could lead.

\section{The Composition of the Court}

Peacock, Couch and Hobhouse embodied a particular kind of expertise. Their dominance, confidence and - particularly in the case of Hobhouse - omnipresence in the Privy Council in the later nineteenth century might give the impression that the value of such expertise was universally recognised. But in fact the Privy Council had, from the very outset, had an ambivalent attitude towards expertise, and once Couch and Hobhouse had retired in 1901, Peacock having died in 1894, there was a notable absence of colonial experience and expertise on the Judicial Committee. 
The Privy Council's ambivalent attitude towards expertise could be traced all the way back to Brougham's 1828 speech. There he had highlighted that one aspect of the difficulty of distance was the inevitability of difficult cases from foreign systems coming "before the necessarily ignorant privy councillor, after the learned doctors of each [jurisdiction] have differed". ${ }^{59}$ His proposed solution, however, was not quite what we might have expected: "The judges should be men of the largest legal and general information, accustomed to study other systems of law beside our own, and associated with lawyers who have practised and presided in the colonial courts. ${ }^{, 60}$ The experienced colonial specialists, in other words, were not to be Privy Council judges, they were to work with those judges in some unspecified way. When Brougham had the opportunity to realise his proposals for reforming the Privy Council, he retained this arms-length distance between decision-making and expertise, by specifying in s 30 of the Judicial Committee Act 1833 that two former colonial judges might be appointed to "attend the Sittings" of the Committee; the membership of the Committee had been set out in $\mathrm{s} 1$ of the Act, in a series of criteria that emphasised high judicial experience in English courts.

The colonial judges appointed under s 30 of the 1833 Act became known as "assessors", and were typically called on in appeals from India. They included highly respected individuals of undoubted intellectual ability, such as Sir Lawrence Peel, who had been Chief Justice of the Supreme Court of Calcutta from 1842 to $1855 .{ }^{61}$ Unfortunately, a lack of sources makes it impossible to assess the assessors' contribution ${ }^{62}$, but it is worth noting that, as part of a

\footnotetext{
${ }^{59} \mathrm{HC}$ Deb, $2^{\text {nd }}$ ser, $7^{\text {th }}$ February 1828 , vol 18 , col 155.

${ }^{60}$ Ibid col 156.

${ }^{61}$ G Boase, rev R Steam, 'Peel, Sir Lawrence (1799-1884) judge in India' in Oxford Dictionary of National Biography.

${ }^{62}$ P Howell, The Judicial Committee (n 6) 156-158.
} 
wide-ranging critique of English judicial dealings with Hindu law, W C Petheram, a former Chief Justice of the Supreme Court of Calcutta, particularly regretted the statutory abolition of assessors. ${ }^{63}$ Their role was invaluable, Petheram argued, when the Privy Council was called upon - as it often would be under Hindu and Muslim law - to identify a prevailing local custom. In such circumstances an assessor might be able to make inquiries that could not properly be undertaken by a judge in the case.

The potential for colonial judges to play a more central role in the decisions of the Privy Council occurred in 1871, when the Judicial Committee Act provided for four new judicial posts. The Act had a troubled history and a sharply contested passage through Parliament, neither of which could be obviously explained by its mundane, rather pedestrian provisions. As both its history and the debates surrounding it demonstrated, however, the proposal to appoint four new judges to the Privy Council, and even the terms of the new appointments, brought to the surface some of the conflicting aspirations, ideologies and fantasies about the Privy Council that were normally left to swirl around its operations unarticulated. At the heart of these disputes were questions about technical expertise, professionalization and the symbolic significance of remuneration for Privy Council judges.

What made such legislation necessary was the number of Privy Council appeals from India, which had climbed so steeply in the 1860 s as to overwhelm the Privy Council's working methods. ${ }^{64}$ In 1870 Lord Westbury brought it to the House of Lords' attention that there were 370 outstanding Privy Council appeals, which, by his calculations, would take an ordinary court of common law two years to get through. This was bad enough, but the Judicial Committee of the Privy Council, as then constituted, could never have achieved such

\footnotetext{
${ }^{63}$ W C Petheram, 'English Judges and Hindu Law' (1900) 16 LQR 392, 395-396. The Appellate Jurisdiction Act 1887 made assessors full members of the Judicial Committee of the Privy Council.

${ }^{64}$ Howell, Judicial Committee (n 6) explains the underlying causes of the increase at 112-118.
} 
productivity: pursuant to s 1 of the Judicial Committee Act 1833, the majority of its members already held high judicial offices that occupied most of their time.

The obvious solution was to reinforce the Privy Council with judges who could devote their energies to clearing the backlog, and in July 1870 Lord Hatherley LC introduced a Bill into the House of Lords which was designed to achieve that result. ${ }^{65}$ The Bill provided for the appointment of four new members of the Judicial Committee. Two were to be either former judges of any High Court in India or a former Law Member of the Viceroy's Council, and were to receive a salary of $£ 1,000$. The second two were to be either former judges of the Supreme Court of any possession other than India, or barristers of at least fifteen years' standing. These second two judges were each to receive $£ 2,500$ a year in salary. The Bill also provided for the appointment of retired English judges, at a salary of $£ 500$ a year. Hatherley clearly anticipated that the details of his proposals would be controversial: as he introduced the Bill for its Second Reading, he was already prepared to restrict the Indian judicial qualifications to former Chief Justices, since, as he explained, "There had been intimated to him some objections with reference to the appointment in the first instance of the Judges in any Court in India, and it had been suggested that in some Courts there were native Judges whom it would not be desirable to appoint as members of the Judicial Committee."

Lord Cairns immediately voiced different anxieties. For him, the eligibility of even former Chief Justices of smaller colonies went too far: "the consequences", he pointed out, "might be the appointment of the Chief Justices of Sierra Leone, the Straits Settlements, Gambia, the Mauritius, or any of the Colonies whose Chief Justices were of a different stamp from those

\footnotetext{
${ }^{65}$ HL Deb 14 July 1870, vol 203, col 239.

${ }^{66}$ HL Deb $18^{\text {th }}$ July 1870 vol 203 , col 405.
} 
whom it was desirable to appoint on the Judicial Committee". ${ }^{67}$ This was hardly flattering to the current holders of those posts. The proposal to pay $£ 500$ to retired English judges was also objectionable, but for different reasons. There was, he said, "an ample scale of retiring pensions for Judges, and attached to the receipt of those pensions there was always considered to be the obligation - no doubt an imperfect one - to give some portion of their time to the transaction of the judicial business of the country". ${ }^{68}$ Introducing a practice of payment, he concluded, would destroy "the honourable understanding which now prevailed". 69

Before we go on to consider how the 1870 Bill fared in subsequent debates it is worth pausing to register the significance of the proposals and the immediate moves responding to them. As it stood the Bill was very obviously shaped by anxieties about the difficulty of distance. The emphasis on former Indian judges was partly explained by the severe backlog of Indian appeals, but the intention to appoint two such judges alongside judges from other colonies showed that, at least in some quarters, there was a belief that what the Privy Council needed was an infusion of new members with colonial experience. Hatherley's concession on Indian judges, and Cairns' concerns about colonial Chief Justices suggested a contrasting underlying conception of the Privy Council. For them it was not all about local knowledge and experience, nor could it be about making the Privy Council a kind of facsimile of an appellate court for whichever jurisdiction an appeal came from - it that were so, the native judges and colonial chief justices would have been a perfect fit. What exactly Lord Hatherley and Lord Cairns had in mind is more difficult to pin down. Their objections could, it is true, simply be read as expressions of racism and intellectual snobbery respectively, but it might

\footnotetext{
${ }^{67}$ HL Deb $18^{\text {th }}$ July 1870 vol 203, col 406.

${ }^{68}$ HL Deb $18^{\text {th }}$ July 1870 vol 203, cols 406-7.

${ }^{69}$ HL Deb $18^{\text {th }}$ July 1870 vol 203, col 407.
} 
be possible - and also more interesting - to relate their concerns to the difficulty of distance. Both men could be seen as saying that over-enthusiastic attempts to eliminate distance would be counter-productive, and result in the appointment of individuals who were either partisan, or unable to appreciate the Privy Council's role as an imperial institution, in which breadth of view and an awareness of political sensitivities were at least as important as technical expertise. They may, in short, both have felt that a certain distance was essential for the Privy Council to perform its role.

When the House of Lords considered the Bill at the Committee stage, attention focussed on its financial aspects. Like Lord Cairns, Lord Romilly opposed the proposal to pay retired English judges $£ 500$ a year, but his reasons were very different from Lord Cairns’. Romilly’s basic position was that there was a direct relationship between remuneration and quality of service, and it was "perfectly ridiculous" to think that $£ 500$ would be enough to secure judges "such as would inspire confidence among the public and the profession both at home and abroad" ${ }^{70}$ He also had his doubts about whether $£ 2,500$ would be enough to tempt barristers of the requisite calibre away from practice. ${ }^{71}$ Lord Cairns agreed, pointing out that English puisne judges currently received $£ 5,000$; if $£ 2,500$ was an adequate attraction, he added, mischievously, "the judicial salaries paid in this country ought at once to be reduced by onehalf". 72

By the time the Bill came to be considered in the Commons, what was described as "very general objection... in the legal profession"73 to the proposal to appoint experienced

\footnotetext{
${ }^{70}$ HL Deb 21 July 1870 vol 203, col 625.

${ }^{71}$ HL Deb 21 July 1870 vol 203, col 625. See also Romilly's comments on the Third Reading, HL Deb 25 July 1870 vol 203, cols 865-6.

${ }^{72}$ HL Deb 21 July 1870 vol 203, col 626.

${ }^{73}$ HC Deb 8 August 1870, vol 203 col 1708 (Mr Bruce).
} 
barristers had resulted in that part of the Bill being dropped. But what was left was still controversial. The Bill, it was said, "went to degrade one of the greatest Courts in the country" 74 , and would make an addition to the Privy Council which "was not equal to the elements of which it is now composed" ${ }^{75}$ Henry James MP (later, as Lord James of Hereford, a Lord of Appeal in Ordinary) singled out the proposal to include former Law Members of the Viceroy's Council - "With the greatest respect to Mr Maine", he said, using that formula that lets listeners know to brace themselves for something disrespectful, "a gentleman whose great learning was admitted, he could not think that the proposal to put among the Judges of the Judicial Committee a gentleman who had had no judicial experience was at all a satisfactory one". ${ }^{76}$ Hobhouse's universally acclaimed service on the Judicial Committee in the last two decades of the nineteenth century would put such casual dismissals in their proper light.

A more considered, compelling attack on the Bill came from Watkin Williams MP. Like his colleagues, he feared that the proposals would diminish the Privy Council's status, but, rather than confining himself to vague generalisations, he was careful to explain why he thought that the current court had such high standing. The Judicial Committee, he said,

had exercised its functions not only to the satisfaction of the suitors, but had so advised the Crown in its actions as to place the Committee in the very foremost rank as an appellate tribunal. Its advice and reports were held both in America and France, as well as in England, as judgments of the highest legal authority; and he ventured to say that there was no Appellate Court in the world - none certainly in England - that could for one moment stand side by side as regarded reputation

\footnotetext{
${ }^{74}$ Ibid cols 1717-8 (Mr Vernon Harcourt).

${ }^{75}$ Ibid col 1714 (Mr Henley).

${ }^{76}$ Ibid cols $1715-6$.
} 
with that great Court. There was no pretence for saying that the House of Lords could be compared with the Judicial Committee in that respect; perhaps one reason was that the Judicial Committee gave their advice to the Crown upon grounds of plain justice and common sense unfettered by technicalities. ${ }^{77}$

The trouble with the Bill, he explained, was that it made belonging to this distinguished tribunal "a matter of money":

Men of the greatest attainments looked to this position as the highest distinction that could be conferred upon them in recognition of public services, great learning, and proved judicial qualifications. But, by making it a question of money, the whole system was altered, and the existing attraction done away with... There was something which, even to lawyers, was more than money, and that was the honourable recognition of the legal ability, learning, and judicial qualifications requisite for the highest appellate tribunal. ${ }^{78}$

Watkin Williams' assessment of the Privy Council, and his criticism of the Bill's proposals were highly suggestive. The Privy Council was depicted as enjoying an enviable international prestige, even in jurisdictions that fell outside its remit, and as being unquestionably ahead of the Appellate Committee of the House of Lords in its standing. Part of the reason for its success, apparently, was its reliance on "plain justice and common sense unfettered by technicalities". In this assessment there was no emphasis on local knowledge or legal expertise in foreign systems - indeed, on Watkin Williams' analysis such factors might tend to distract the court from what had made it such a success. The same theme shaped Watkin Williams' objections to the Bill: there was nothing in his comments to suggest that he thought

\footnotetext{
${ }^{77}$ Ibid cols 1711-2.

${ }^{78}$ Ibid cols 1712-3.
} 
particular kinds of expertise or colonial experience were either necessary or desirable in Privy Council judges. On the contrary, appointment to the Privy Council was seen as an honour with congenial duties attached. To put it in terms of distance, on Watkin Williams' view distance did not matter; the secret of the Privy Council's success was that it dispensed plain justice and common sense, and those two commodities were the same the world over.

Despite valiant attempts by Gladstone, who appealed to the House's “character for justice and business habits" ${ }^{\text {,79 }}$, the government could only muster a bare majority in favour of the proposals, and the Bill had to be abandoned. The backlog of appeals increased, and less than a year later Lord Westbury sought to force the issue, by demanding the introduction of a Bill within ten days. ${ }^{80}$ There were now, he claimed, four hundred appeal cases waiting. In the course of his speech Westbury pointed out that there were murmurings of discontent in the colonies; he quoted from an article in the Melbourne Argus that complained about the delays, and which continued "All we ask is that our suits shall be decided by a fully organized English Court, and not by some stray legal casuals." ${ }^{~} 81$ The latter phrase was perhaps a disparaging reference to the broad categories of eligibility in the failed 1870 Bill; but the more eye-catching point was at the start of the sentence: this Australian writer wanted a proper English court to decide Australian appeals. It was as if, paradoxically, the presence of anyone other than English judges somehow devalued the court.

Hatherley's immediate response to Westbury's demands was to prevaricate. But eleven days later (and we might wonder whether he was making a subtle point with this timing) he introduced the Judicial Committee Bill 1871. ${ }^{82}$ The Bill proposed to appoint four new Privy

\footnotetext{
${ }^{79}$ Ibid 1717.

${ }^{80}$ HL Deb 15 June 1871 vol 207 col 53.

${ }^{81}$ Ibid col 55 .

${ }^{82}$ HL Deb 26 June 1871 vol 207, col 555.
} 
Council judges, who must have been either judges of the Superior Courts at Westminster, or Chief Justices of Bengal, Madras or Bombay. These criteria were obviously far narrower than those in the earlier proposal, and prompted no objections in the Bill's passage through both Houses, although Lord Westbury suggested that "ultimately" Irish and Scottish judges should be eligible for such positions. ${ }^{83}$ As it turned out, however, the real controversy would come when the Act was implemented. Sir James Colvile and Sir Barnes Peacock accepted two of the posts, and Sir Montague Smith, previously of the Court of Common Pleas at Westminster took the third. The fourth appointment, however, was problematic: no Westminster court judge wanted it $^{84}$, so Gladstone, in desperation, appointed his Attorney General, Robert Collier, to a vacant position in the Court of Common Pleas before translating him to the Privy Council after two days. ${ }^{85}$ The "Collier Juggle", as it became known, is perhaps more significant as an episode in Gladstone's political career than in the history of the Privy Council $^{86}$, but, even so, it still casts some light on contemporary attitudes to the Privy Council's role. For what is striking from the legal perspective is that, although the Lord Chancellor envisaged appointing two judges with English judicial backgrounds and two from

\footnotetext{
${ }^{83}$ HL Deb 4 July 1871 vol 207, col 1094.

${ }^{84}$ It seems that the Westminster judges to whom the position was offered were unwilling to have to dismiss their long-standing clerks (clerks not being needed for Privy Council judicial duties): Howell, The Judicial Committee (n 6) 151. Cf R Stevens, 'The Final Appeal: Reform of the House of Lords and Privy Council 18671876' (1964) 80 LQR 343, 348, who suggests that the salary of £5000 was not attractive enough.

${ }^{85}$ D Pugsley, 'Collier, Robert Porrett, first Baron Monkswell (1817-1886), judge' in Oxford Dictionary of National Biography; more vivid language is used to describe the affair in 'Death of Lord Monkswell' The Times (London, 28 October 1886) 6 ("flagrant violation of the spirit of the enactment"; Collier "no doubt a reluctant actor in the comedy"; "This mockery aroused indignation such as has been evoked by no other appointment in modern times".)

${ }^{86}$ R Jenkins, Gladstone (Macmillan, 1995) 369.
} 
India ${ }^{87}$, the Act allowed more flexibility by providing simply for four new judges, each of whom had to meet one of the criteria (whether English or Indian) for appointment. ${ }^{88}$ There was, in other words, no necessity to have manufactured a candidate with English judicial qualifications. That Gladstone chose to do so, rather than appointing a third judge with high Indian experience, may suggest that, for him, it was essential to maintain a symmetry between home and colonial perspectives in the Privy Council.

The 1871 Act marked the end of attempts systematically to integrate colonial judges into the Privy Council. The question of who ought to sit in the Judicial Committee quickly became caught up in broader debates about appellate jurisdiction more generally; one result of those debates was the Appellate Jurisdiction Act 1876, which provided for the appointment of four Lords of Appeal in Ordinary, who would hear both House of Lords and Privy Council appeals. The 1876 Act provided for two Lords of Appeal in Ordinary to be appointed immediately; the third to be appointed on the death or resignation of two of the appointees under the 1871 Act; and the fourth once the final two 1871 Act appointees were out of the picture. This shift in the balance of power did not go unnoticed. As the Times observed on the occasion of the death of Sir James Colvile in 1880, his loss was irreparable in a special sense. His service as, first, a judge, and then as Chief Justice of the Supreme Court of Bengal had given him an enviable grasp of Indian law, which he combined with "an understanding of the spirit of universal justice" ${ }^{89}$ But these were not unique qualities - they could also be found among former Law Members of the Viceroy's Council, for instance. "It is not the dearth of competent successors", the Times explained, "but legislation which has rendered SIR JAMES COLVILE'S loss irreparable, by providing that it shall not be repaired... Starving the

\footnotetext{
${ }^{87}$ HL Deb 29 June 1871vol 207, col 725.

${ }^{88}$ Judicial Committee Act 1871 s 1.

${ }^{89}$ The Times (London, 9 December 1880) 9.
} 
Supreme Court of Appeal for the whole of the residue of the Empire seems a roundabout way of securing an efficient Appeal Court for Scotland and Ireland." 90

\section{Universal Principles}

In the years after 1876, the Privy Council's pretensions to expertise in the systems from which it heard appeals inevitably became more tenuous. That might have appeared to undermine its authority; but the fact that the Privy Council did not suffer any marked loss of respect indicates that other strategies for negotiating the difficulty of distance were being successfully resorted to. One of the most interesting, and frequently used, of those strategies was the attempt to transcend distance by an appeal to general, transnational principles.

This judicial technique was described with particular eloquence by Lord Haldane, who, as well as being a member of the Judicial Committee from 1911, had had an extensive practice before the court prior to that. ${ }^{91}$ We saw earlier that Haldane had enormous admiration for Lord Watson, whom he described as "the Privy Council judge par excellence" ${ }^{\text {"92 }}$. Haldane's admiration stemmed partly from Watson's apparent ability to become a lawyer of the system from which the appeal was brought; but he was also deeply impressed by Watson's general legal abilities. "Fine legal intelligence", observed Haldane,

even in a comparatively unfamiliar field, is better than the understanding whose main qualification is only special knowledge. The jurisprudence of all countries is much the same in its fundamental principles. Strip it of its technical terminology,

\footnotetext{
90 Ibid.

${ }^{91}$ Haldane, 'The Work for the Empire of the Judicial Committee of the Privy Council' (1921-1923) 1 CLJ 143, 146.

${ }^{92}$ Haldane, 'The Appellate Courts of the Empire' (1900) 12 Juridical Review 1, 5. Above, p. XXX.
} 
and the differences in great measure disappear. The master of legal principle who has a mind large enough to be free from provincialism is, therefore, in all cases the best kind of judge..$^{93}$

Haldane was speaking in 1900, and, given the relatively recent controversies surrounding the appointment of colonial judges to the Privy Council, his remarks are particularly striking: rather than regretting the loss of specialist expertise among the judges, expertise was here being presented as inhibiting, narrowing, and halfway to provincialism.

Twenty years later, in a similar address, Haldane returned to the same theme:

The Judges try to look for the common principle underlying systems of jurisprudence of differing kinds. They know that the form often veils over a very similar substance. We are constantly finding that, where great broad principles of justice are concerned you find - veiled, but still there, and only distinguished by technicalities - the same substance as belongs to other systems. The human mind is much the same all the world over. ${ }^{94}$

In some ways this passage is even more suggestive than his earlier remarks. He was now a judge - hence the slide from the third person to the first - and though he began his talk with some light-hearted comments about keeping the Privy Council's secrets, he obviously found the occasion congenial, and it may be relevant that he had not planned to publish the text of what he said. ${ }^{95}$ His comments showed how far he was from thinking that specialism, or expertise in a particular system, were advantages: on the contrary, an immersion in the technicalities was to be avoided, and the veils thrust aside. The last sentence of the passage

\footnotetext{
${ }^{93}$ Ibid, 5-6.

${ }^{94}$ Haldane, 'The Work for the Empire' (n 91) 154.

${ }^{95}$ A L Goodhart, 'The Origin of the Journal' (1972) 31 CLJ 4, 6-7.
} 
was particularly resonant: if the universal identity of the human mind was the starting point, the difficulty of distance disappeared.

The attraction of appealing to universal principles of justice was particularly strong when social conditions and legal concepts were remote from those applying in England. Two examples from the Indian appeal cases on duress and undue influence show how such universal concepts could be invoked, with varying degrees of success. In Prem Narain Singh $v$ Parasram Singh ${ }^{96}$ the appellants sought to set aside an agreement under which they had transferred a half share of property inherited from their grandfather to their uncles and cousins. The property had previously been held by the appellants' grandmother; after her death, the defendants arrived with a large body of retainers, and took possession. There were "serious apprehensions of affray" "97, and government officers had to be sent to keep the peace. A "punchayet" was then held, at which the arbitrators were the father-in-law of the eldest appellant and two neighbouring "zemindars". None of the Indian terms were explained in the Privy Council's reasons, but a punchayet was a kind of mediation, and a zemindar a local landowner. The outcome of the punchayet was an ikrarnamah (again, unexplained in the reasons - it meant a formal undertaking) to transfer the half-share. The appellants then went before a criminal court, where they made depositions stating that they had been charged with unlawful assembly, that they denied the charge, and that the transfer of the property had been made as a compromise. Having explained the facts, the Privy Council then proceeded to apply the law:

Looking at the whole case, the main features of it appear to be these: These young men execute a deed, whereby they part with a half of their property. It is, in their

\footnotetext{
${ }^{96}$ (1877) LR 4 Ind App 101.

97 (1877) LR 4 Ind App 101, 105.
} 
Lordships' view, executed without any consideration whatever. It is executed very shortly after they had come to their property, and when it may be considered as at all events doubtful whether they were fully acquainted with their rights; indeed the evidence in the case tends to shew that they were not fully acquainted with their rights. At the time of the execution of a most important document they do not appear to have had any professional advice; and, further, the appearance of their uncles with a large force, the possession which was taken of their property, the criminal proceedings, and the other circumstances which have been referred to, constituted a state of things likely to overawe them, and materially to affect the free exercise of their will. ${ }^{98}$

The effect of this paragraph is a linguistic jolt. Up to this point the events had been described in a way which made no concessions to readers unfamiliar with Indian terminology. But when it came to the legal analysis, the "main features" of the case were articulated in such classical English legal language as to sound faintly ridiculous. There is also a troubling sense that by forcing the factual situation into English legal categories the "main features" of the case were misidentified as being all about the appellants' exercise of their contractual freedoms. A different way of characterising the case would have focussed on the appellants' attempts to renege on the outcome of a local mediation. Indeed, it might be tempting to say that the "main feature" of the case was the delicate issue about the extent to which different, local traditions of resolving disputes should be respected. The Privy Council's approach to the case as a question of undue influence inevitably pushed the issue of legal pluralism to one side.

\footnotetext{
98 (1877) LR 4 Ind App 101, 108.
} 
A more convincing invocation of universal principles could be seen in Moung Shoay Att v Ko Byaw $^{99}$, an appeal from the Special Court of British Burma. Here the question was whether a sale of timber at an exorbitant price was void for duress, with the alleged duress taking the form of a violent arrest, beating and imprisonment of the buyer's agent by a Burmese officer, following a complaint about the agent's conduct by the seller. The agent had agreed to the sale after this ordeal. The Privy Council felt able - although with some caution - to have recourse to general principles, saying that:

No doubt, speaking generally, all matters relating to a contract are to be decided by the law of the country where the contract is made, but there are principles of universal application by which all contracts, wherever made, must be judged. The first principle of contracts is, that there should be voluntary consent to it. ${ }^{100}$

However, at the same time, great care was taken to signal that the judges appreciated the importance of local conditions. One of the arguments that had been addressed to them was that since the Burmese officer's imprisonment of the agent was lawful, the buyer could not rely on it as duress. The judges' response to this argument was quick to distinguish between England and Burma:

in this country if a man is under lawful imprisonment for a civil debt, an agreement which he makes while subject to that constraint is not, by reason of his being so subject to it, capable of being avoided, provided that it is not unconscionable. But imprisonment in a country where there is no settled system of law or procedure, and where the judge is invested with arbitrary powers, is duress of a wholly different kind. In the one case the prisoner knows that the

\footnotetext{
${ }^{99}$ (1876) LR 3 Ind App 61.

100 (1876) 3 LR Ind App 61, 65.
} 
length and severity of his imprisonment are defined and limited by the law, and cannot be exceeded; whereas in the other the prisoner neither knows what will be the length of his imprisonment, nor what amount of pain and misery he may be put to; all is indefinite; and therefore the apprehension acting on the mind of a man in such a situation would be infinitely greater than if he were imprisoned in a country like England, where the law is settled, and cannot be exceeded by the Judge. $^{101}$

The sale was, therefore, held to be void.

Part of what made Moung Shoay Att $v$ Ko Byaw a more convincing performance than Premain Narain Singh v Parasram Singh was its tone: the universal contractual principle on which reliance was to be placed was put forward almost diffidently, and wrapped in the reassuring acknowledgement that local law was paramount. There were no such presentational niceties in Singh's case, where English legal categories were simply imposed. Of equal, perhaps greater importance, was the superior way in which Moung Shoay Att v Ko Byaw negotiated the difficulty of distance. In Singh's case the facts were in Bengal, and the law was in London; but in Moung Shoay Att v Ko Byaw the judgment was nimbler, shuttling astutely between anglicised universal principles and Burmese particularities to craft an analysis that was strengthened by its interweaving of different strands.

\section{Policy}

For a court to be undertaking the identification and exposition of universal principles was, perhaps, unusual enough; but the Privy Council's frequent and unabashed engagement with

101 (1876) 3 LR Ind App 61, 65. 
questions of policy made it unique among English courts. A particularly vivid illustration, and one in which the connections between policy and distance were expressly articulated, was provided by Madras Railway Company v Zemindar of Carvatenagarum. ${ }^{102}$

The facts concerned an irrigation tank maintained by the defendant, which had burst following extraordinarily heavy rainfall in the monsoon season. The water escaped, damaging the claimant's railway line, and the claimants sought compensation based on the then recent House of Lords' decision in Rylands v Fletcher. ${ }^{103}$ Holloway CJ, hearing the case in the High Court of Madras, was appalled. In an unusually vigorous judgment rejecting the claim, he pointed out that the tanks had existed since "beyond living memory", were "absolutely necessary to human existence, so far as it depends upon agriculture", and that the imposition of liability would be "calamitous" for the local population. ${ }^{104}$ These instinctive expressions of alarm were accompanied by combative legal analysis. "A rule of law", he said, "is not a rule for us, unless it is a correct rule, and it is quite possible that a rule excellent there may be wholly inapplicable here."105 The particular rule he had in mind was the proposition that storage of a large quantity of water was a non-natural use of land, for the escape of which the owner of the land was strictly liable. This was, undeniably, the ratio decidendi of Rylands $v$ Fletcher, but, as Holloway CJ pointed out, it did not travel well:

The test here proposed is whether the accumulation took place in the course of the natural user of the close. Now it is very obvious that the most natural user of land

\footnotetext{
102 (1874) LR 1 Ind App 364.

103 (1868) LR 3 HL 330.

${ }^{104}$ Madras Railway Company v Zaminda'r of Ka'vatinaggur (1871) 6 Mad HC 180. The quotations are taken from pages 182, 183 and 187 respectively. The lack of a uniform method of transcribing Indian proper names caused problems for law reporters: F Pollock, 'English Law Reporting' (1903) 19 LQR 451, 455.

105 (1871) 6 Mad HC 180, 183.
} 
is for the purposes of agriculture, and that in England, until the summer of 1868, it never entered into the head of any Englishman that the storing up of large quantities of water could be essential to agriculture. ${ }^{106}$

Where the climate made storage of water necessary for agriculture, the rule subverted its own rationale. Holloway CJ had no doubt about which should prevail: "although not an immediate, national economy, wealth and prosperity, with all other objects of man's ethical interests, are mediate sources of law."107 It followed, therefore, that storage of water under these circumstances was a natural user, which could not give rise to liability under Rylands $v$ Fletcher. This analysis was emphatic enough already, but Holloway CJ had, as it turned out, saved his most withering comments for a parting shot: "this attempt [to rely on Rylands $v$ Fletcher] would never have been made if the final decision had rested with Judges conversant with the necessities of the country, and ... it has only been made in the hope that such a rule may be imposed elsewhere by Judges not so conversant". ${ }^{108}$ The claimants, he believed, were cynically hoping to exploit the Privy Council's ignorance of Indian conditions for their own advantage.

Holloway CJ's colleague Innes J was less outspoken and preferred a different route to the denial of liability. For Innes $\mathbf{J}$ the key point was that the maintenance of these tanks was "impressed with the character of lawfulness". ${ }^{109}$ It had obtained this character because elsewhere in India the state itself undertook maintenance of the tanks; the defendant was,

\footnotetext{
${ }^{106}$ (1871) 6 Mad HC 180, 184.

107 (1871) 6 Mad HC 180, 185-186.

108 (1871) 6 Mad HC 180, 186.

109 (1871) 6 Mad HC 180, 189.
} 
therefore, in the same position as people carrying on "dangerous trades and occupations in England for which there is legislative sanction". 110

When the case was decided by the Privy Council, the less pugnacious approach of Innes $\mathbf{J}$ was preferred. The Judicial Committee was not persuaded that Rylands $v$ Fletcher was inapplicable to India because, "decided as it was, on the application of the maxim, sic utere tuo ut alienum non laedas, [it] express[ed] a principle recognized by the laws of all civilized countries". ${ }^{111}$ That was not to say, however, that it was indistinguishable. Here the tanks formed part of a national system of irrigation the importance of which was universally acknowledged; the zemindars had a public duty to maintain them, which had no counterpart in the facts of Rylands $v$ Fletcher. "The rights and liabilities of the Defendant", the Board concluded, "appear to their Lordships much more analogous to those of persons or corporations on whom statutory powers have been conferred and statutory duties imposed."112

The Madras Railway case exemplifies virtually all of the fundamental themes of this essay. The difficulty arising from distance was recognised - even strenuously signalled - by Holloway CJ; the need for the common law to adapt in different physical and social circumstances was acknowledged; and the recourse to universal principles in order to give transnational authority to English legal rules was prominent. There was even, in Holloway CJ's comments about the Privy Council's ignorance of colonial conditions, an allusion to the vexed issue of judicial expertise. As things turned out, that was one issue on which Holloway CJ need not have been apprehensive, for later that same year the Judicial Committee Act would (as we have seen) clear the way for two former Indian Chief Justices to be appointed

\footnotetext{
${ }^{110}$ (1871) 6 Mad HC 180, 190.

111 (1874) LR 1 Ind App 364, 385.

112 (1874) LR 1 Ind App 364, 385-386.
} 
to the Privy Council. But in one crucial respect the Madras Railway case highlighted a further, potentially deeply controversial aspect of the Privy Council's work, which was its readiness to decide cases on policy grounds. Here, for all the attention-grabbing pungency of Holloway CJ's judgment, Innes $\mathrm{J}$ and the Privy Council were doing something extraordinarily radical: they were granting an exemption from liability as if there were a statute authorising the activity when no such statute actually existed. It was, in effect, nothing less than the creation of a public interest exception.

It is perhaps surprising that more has not been made of the Madras Railway case, especially in view of the continuing fraught relationship between liability in nuisance and questions of public interest. ${ }^{113}$ It may, perhaps, have been a victim of law reporting conventions, with its appearance in the Indian Appeal Cases series being taken as a sign that it was of Indian interest only. Certainly that is how it seems to be seen today ${ }^{114}$, but it is interesting to note that Pollock, at least, registered its significance for the general principles of English law. ${ }^{115}$

A revealing contrast can be made in this respect with Victorian Railway Commissioners $v$ Coultas $^{116}$, another Privy Council decision in which tort liability was controlled by policy factors. The appeal was from the Supreme Court of Victoria, and concerned a claim in negligence for shock suffered when, owing to a gate-keeper's negligence, the claimant was

\footnotetext{
${ }^{113}$ Most recently played out in the context of planning permissions: Coventry (t/a RDC Promotions) $v$ Lawrence [2014] UKSC 13, [2014] AC 822.

${ }^{114}$ P Muchlinski, 'The Bhopal Case: Controlling Ultrahazardous Industrial Activities Undertaken by Foreign Investors' (1987) 50 Modern Law Review 545, 564-566, especially at 565, where the Madras Railway case is said to show that Rylands v Fletcher "has been applied with Indian circumstances in mind".

${ }^{115}$ F Pollock, 'Duties of Insuring Safety: The Rule in Rylands v Fletcher' (1886) 2 LQR 52, 58.

${ }^{116}$ (1888) 13 App Cas 222.
} 
nearly hit by a train. The Australian court had thought the claim a legitimate one ${ }^{117}$, but the Privy Council's view, in reasons delivered by Sir Richard Couch, was very different: the damages were held to be too remote to be recovered, but the language used indicated that this was, in effect, a policy decision. Allowing the claimant to recover here, it was said, would "result in a wide field being opened for imaginary claims". ${ }^{118}$ The Privy Council's decision inspired the creation of a new rule of liability - the rule in Wilkinson $v$ Downton ${ }^{119}-$ which $^{2}$ attempted to circumvent the denial of liability by awarding damages where the defendant's mental state was (slightly) more culpable than negligence. Later English courts also hesitated to endorse the Privy Council's confident dismissal of such claims. ${ }^{120}$ The Privy Council, it seemed, had greater freedom to manoeuvre on policy matters than its English counterparts.

\section{Refusing to Decide}

Perhaps the best known examples of the Privy Council exercising such freedom in cases of policy occurred in the second half of the twentieth century when, beginning with Australian Consolidated Press Limited v Uren ${ }^{121}$, the Privy Council decided that there were, in effect, some cases that it could not legitimately decide. The Australian Consolidated Press case concerned the availability of exemplary damages in claims for defamation. In England the circumstances in which such damages could be recovered had been dramatically curtailed by

\footnotetext{
${ }^{117}$ Coultas $v$ The Victorian Railway Commissioners (1886) 12 VLR 895.

${ }^{118}$ (1888) 13 App Cas 222, 226.

${ }^{119}$ [1897] 2 QB 57. Wainwright v Home Office [2004] 2 AC 406, [36]-[41].

${ }^{120}$ Dulieu $v$ White \& Sons [1901] 2 KB 669, 677 (Kennedy J).

${ }^{121}$ [1969] 1 AC 590.
} 
the House of Lords' decision in Rookes v Barnard ${ }^{122}$ a couple of years earlier, but Australian courts were minded to retain the earlier position. The matter came to a head when the High Court of Australia ruled that exemplary damages were available for insolent, vindictive, outrageous or high-handed disregard of the claimant's rights, and that the Rookes $v$ Barnard categories should not be applied in Australia. ${ }^{123}$ The Privy Council dismissed the appeal, saying that:

in a sphere of the law where its policy calls for decision and where its policy in a particular country is fashioned so largely by judicial opinion it became a question for the High Court to decide whether the decision in Rookes $v$ Barnard compelled a change in what was a well settled judicial approach to the law of libel in Australia. Their Lordships are not prepared to say that the High Court were wrong in being unconvinced that a changed approach in Australia was desirable. $^{124}$

The same underlying theme could be seen in Lange $v$ Atkinson ${ }^{125}$, another Privy Council appeal on defamation, which raised questions about the extent of the protection offered by the common law to political expression in New Zealand. As in the Australian Consolidated Press case, the Privy Council felt unable to adjudicate, saying that

striking a balance between freedom of expression and protection of reputation calls for a value judgment which depends upon local political and social conditions. These conditions include matters such as the responsibility and

\footnotetext{
${ }^{122}$ [1964] AC 1129. P Mitchell, The Making of the Modern Law of Defamation (Hart, 2005) 64-70.

${ }^{123}$ Uren v John Fairfax \& Sons Pty Limited (1966) 117 CLR 118.

${ }^{124}$ [1969] 1 AC 590, 644.

${ }^{125}$ [1999] UKPC 46.
} 
vulnerability of the press... For some years their Lordships' Board has recognised the limitations on its role as an appellate tribunal in cases where the decision depends upon considerations of local public policy. ${ }^{126}$

There can be no doubt that this was a highly significant line of cases, but it may be doubted whether, as one commentator observed of the Australian Consolidated Press case, it represented "an apparent change in the Board's conception of its role as an appellate tribunal". ${ }^{127}$ Nearly fifty years earlier, Lord Haldane had written admiringly of the Judicial Committee's skilful refusal to adjudicate on a delicate issue that had arisen on an appeal from Jersey. ${ }^{128}$ For Haldane, such strategies were entirely consistent with the Privy Council's fundamental role and function, which he regarded as revolving around the idea of statesmanship. This was particularly important on constitutional questions. "It is not always that the King can be safely advised to interfere with what belongs to the constitutions or systems of government of the countries of the Empire", he explained,

and so the Judges of the Judicial Committee have been selected because of their training, not only in the law, but because in the case of most of them they have had experience elsewhere - in the House of Commons or in the House of Lords as members of it, or as Chancellors or ex-Chancellors, or by training calculated to give what is called the statesmanlike outlook to the Judge - that is to say, the outlook which makes him remember that with a growing Constitution things are

\footnotetext{
${ }^{126}$ [1999] UKPC 46, [16].

${ }^{127}$ J Lehane, 'Stare Decisis, Judicial Policy and Punitive Damages' (1968) 6 Sydney Law Review 111, 117.

${ }^{128}$ Haldane, 'The Work for the Empire' (n 91) 151.
} 
always changing and developing, and that you cannot be sure that what was right ten years ago will be right to-day. ${ }^{129}$

Statesmanship was not, however, confined to constitutional points. That morning, Haldane told his audience, the Privy Council had refused leave to appeal in three cases from Canada, and given permission in an appeal from the Gold Coast. The decisions had been informed by a sense of the relative maturity and sophistication of the systems from which the appeals had come. Canadians "had got their own fully organized Courts, and their own sense of development, and their own feeling that it is their right to dispose of their own litigation". 130 In the Gold Coast, by contrast, "the tribunal is not developed in the same way, and the Privy Council sits as the guardian Justice to take care to see that justice is done". ${ }^{131}$ It was the hallmark of the statesman to be guided by his sense of whether assistance would be unwelcome or inappropriate. ${ }^{132}$

It is striking how much of Haldane's analysis can be applied to the later decisions. Indeed, one commentator explained the Australian Consolidated Press decision, without reference to Haldane, as a reflection of the High Court of Australia's newly enhanced reputation. ${ }^{133}$ Haldane's analysis also puts in a different light the criticism that, in decisions like the Australian Consolidated Press case and Lange v Atkinson, "the Committee's deference to local assessment effectively denied the appellants in the Judicial Committee their right of

\footnotetext{
${ }^{129}$ Ibid, 148.

${ }^{130}$ Ibid, 153.

${ }^{131}$ Ibid.

${ }^{132}$ Ibid, 154. See also Wallis v Solicitor-General for New Zealand [1903] AC 173, where the Privy Council reversed a decision of the Court of Appeal of New Zealand which it felt was too deferential to the government.

${ }^{133}$ R Heuston, "Damages in Libel” (1969) 1 Dublin University Law Review 23, 26-27.
} 
appeal". 134 "Denial" of a "right" sounds a note of legal formality, but the Judicial Committee seems not to have regarded itself as constrained by forms, or even to have been performing an unambiguously legal (as opposed to political) role. Apparently Lord Devlin remained of the view that it was not a court ${ }^{135}$ - perhaps influenced by the treatment of his speech in Rookes v Barnard in the Australian Consolidated Press case - and it is easy to see why there was uncertainty. The position was one of carefully cultivated ambiguity.

\section{Conclusion}

This essay has sought to identify, illustrate and evaluate some of the ways in which the Privy Council navigated the difficulty of distance. The techniques and their rationales varied widely, and were not mutually consistent. To that extent it is important to recognise that there was not one overall strategy, but, rather, a series of opportunistic attempts to maintain the court's credibility and its moral authority. If there is a central, unifying theme it is the readiness to take advantage of ambiguities about where the court was, what its role was, and, even, whether it was a court at all. Equivocations about location made the difficulties of distance appear less sharp, and the court's strenuous attempts to imagine itself in the jurisdiction from which the appeal came might even appear to dissolve those difficulties altogether. A related strategy involved deliberately positioning one's analysis against the grain of the court's London base; this could be done most effectively by making it clear that, irrespective of the underlying political structures, England had no hegemony in matters of

\footnotetext{
${ }^{134}$ K Keith, 'The Interplay with the Judicial Committee of the Privy Council' in L Blom-Cooper, B Dickson and G Drewry (ed), The Judicial House of Lords 1876-2009 (Oxford University Press, 2009) 315, 326.

${ }^{135}$ Howell, The Judicial Committee (n 6) 37, 222 (where Lord Devlin was said to be "suffering from a romantic delusion" in holding this view).
} 
legal analysis. Questions of expertise and professionalization also prompted carefully equivocal answers, in which both the benefits of specialisation and anxieties about its potentially narrowing effects were in counterpoise. Perhaps most fundamentally, there was an ongoing, unresolved ambiguity about whether the Privy Council was really a court or not. In some rather obvious ways it was. But its formal role as advisor to the monarch, and its location in Downing Street, next to the Prime Minister and the Chancellor of the Exchequer meant that it did not look like a court; and when it talked about matters of policy, or exercised a statesmanlike restraint in questions on which it had been asked to adjudicate, it did not sound like a court either. Its success in negotiating the difficulty of distance lay in the creation of a network of ambiguities and equivocations that it took great care not to resolve. 